\title{
ArcheoSciences
}

Revue d'archéométrie

\section{Testing the use of geostatistical and statistical methods to improve data visualization. Case study on GPR survey of Tarragona Cathedral}

Robert Tamba, Roger Sala and Ekhine García

\section{OpenEdition} Journals

Electronic version

URL: https://journals.openedition.org/archeosciences/1803

DOI: 10.4000/archeosciences.1803

ISBN: 978-2-7535-1599-4

ISSN: $2104-3728$

Publisher

Presses universitaires de Rennes

\section{Printed version}

Date of publication: 30 October 2009

Number of pages: $335-338$

ISBN: 978-2-7535-0943-6

ISSN: $1960-1360$

\section{Electronic reference}

Robert Tamba, Roger Sala and Ekhine García, "Testing the use of geostatistical and statistical methods to improve data visualization.

Case study on GPR survey of Tarragona Cathedral", ArcheoSciences [Online], 33 (suppl.) | 2009, Online since 30 October 2011, connection on 01 February 2022. URL: http://journals.openedition.org/ archeosciences/1803; DOI: https://doi.org/10.4000/archeosciences.1803 


\title{
Testing the use of geostatistical and statistical methods to improve data visualization Case study on GPR survey of Tarragona Cathedral
}

\author{
Robert TAмвA*, Roger SALA ${ }^{* *}$ and Ekhine García ${ }^{* * *}$
}

Key words: Tarragona, cathedral, GPR, geostatistics, urban archaeology.

\section{INTRODUCTION}

The paper presents the results of the use of alternative geostatistical and statistical methods to enhance visualization of the Tarragona Cathedral. These methods improve data homogeneity with time/depth, give alternative timeslice computation using other values than the mean value, and study the impact of the time-window thickness used when generating time-slices. The data used for the project was a GPR prospection of the cathedral accomplished in 2007 by Roger Sala and Ekhine Garcia (SOT Prospecció arqueològica) for the Tarragona Cathedral geophysical research project funded by I.C.A.C. (Catalan Institute of Classical Archaeology). The survey was conducted by a multidisciplinary team coordinated by archaeologist Josep Maria Macias (ICAC) and Dr. Albert Casas (Universitat de Barcelona) with the participation of Dr. Pietro Cossentino's team (University of Palermo) and the SOT Archaeological Prospection Team. Based on ten years of archaeological research (by J. Menchón, I. Teixell, A. Muńoz, J.M. Macías), three different geophysical techniques were employed. The project was coordinated by Casas's team, which was in charge of the 2D electrical tomography and the subsequent
3D integration. Cosentino's team operated 3D electrical tomography and low frequency GPR $(100 \mathrm{MHz})$. The SOT team completed an extended georadar prospection. The objective was to search for possible archaeological remains in the first two meters below ground surface in order to give archaeologists the opportunity to integrate the results of different vertical and horizontal scales given by electrical tomography.

\section{Prospection methodology}

The area of prospection covered the nave and aisles and the transept as one. The altar area, with its ground level situated $0.6 \mathrm{~m}$ above the nave, and the cloister, with its ground level $0.8 \mathrm{~m}$ above the nave, were prospected separately. In order to get results with sufficient vertical range and horizontal definition, the GSSI SIR-3000 system was used with a $270 \mathrm{MHz}$ antenna and 512 samples in a $95 \mathrm{~ns}$ time window saved in 16bits format.

The basilica was explored using a $0.4 \mathrm{~m}$ separation between radargrams and a horizontal resolution of $0.025 \mathrm{~m}$ or 40 scans per meter. As a higher resolution was necessary

\footnotetext{
* Sot prospecció arqueologica. (tamba_of@yahoo.fr)

** Sot prospecció arqueologica. (roger_sala_bar@yahoo.es)

*** Sot prospecció arqueològica. (ekhinegarcia@yahoo.com)
} 
A. Time-slice from 21.8-23.1ns (Calculated 0.9-0.96m depht)
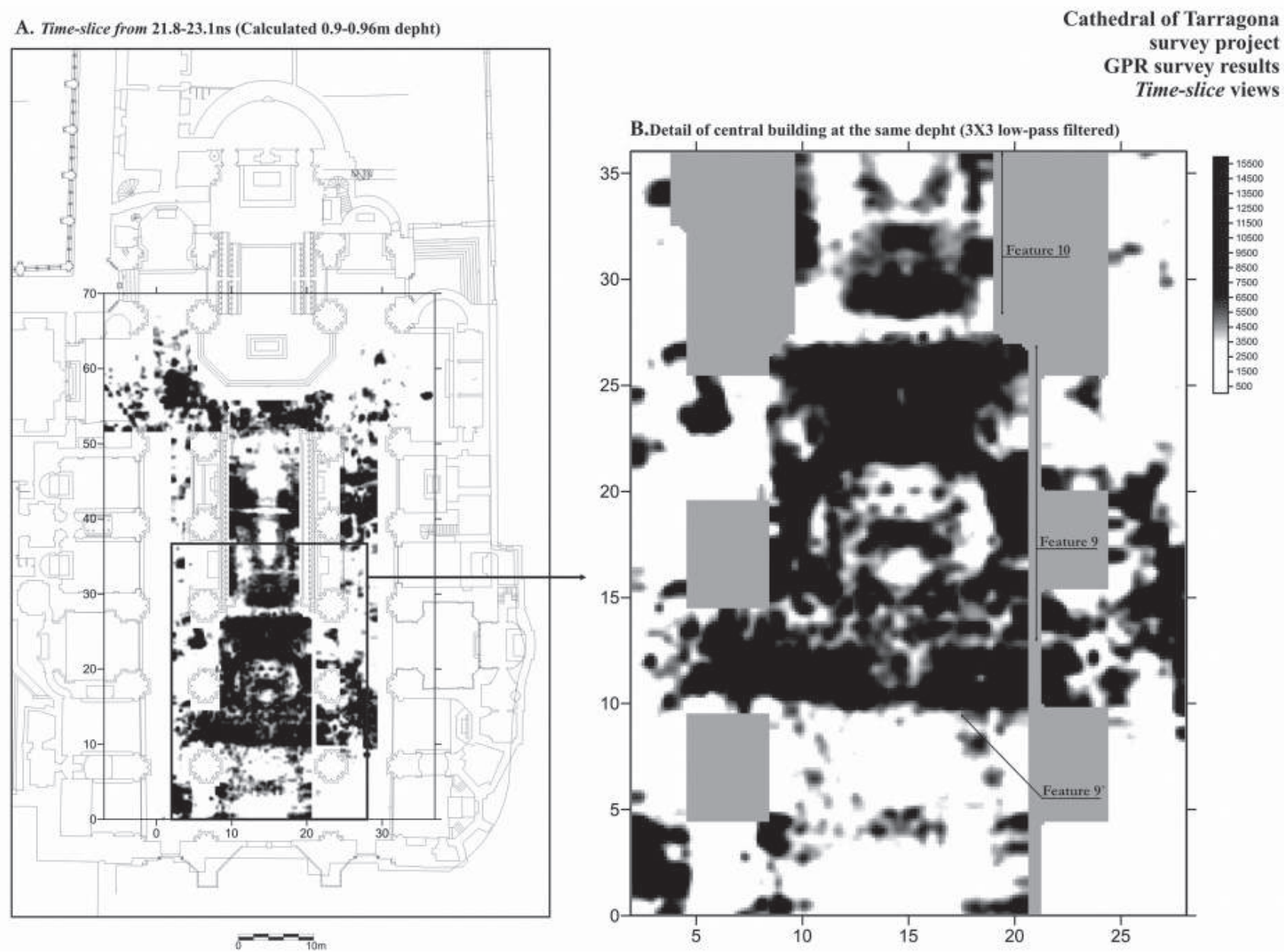

Figure 1: Tarragona Cathedral survey project, GPR survey results - time-slice views. Time-slice from 21.8-23.1ns (Calculated 0.90-0.96 m depth). Detail of central building at the same depth (3X3 low-pass filtered)

in the nave, an additional perpendicular grid was put down in this area. Time-to-depth conversion was performed with a velocity computed through hyperbolas geometry analysis.

The data were processed using the time-slice method which gives horizontal sections that supply the archaeological team with precise information.

\section{RESULTS OF THE PROSPECTION}

The SOT team's experience on similar archaeological sites was very useful for deciding the geometry of processing parameters. Indeed, the thickness of the time window used to create horizontal sections and the radius for interpolation have a straightforward impact on the sharpness and definition of the anomalies.
Within the first two meters below ground surface a minimum of three successive levels was detected in most of the nave extensions under the current pavement. The processing revealed a group of anomalies (9 and 9') located under the nave, at a computed depth of $0.9 \mathrm{~m}$ below ground surface; the axis of symmetry of these remains is similar to that of the cathedral and would suggest the existence of a separate structure.

Further processing reduced the thickness of the time window used for time-slice computation to $6 \mathrm{~cm}$, making it possible to describe the said structure. It features a semicircular perimeter which stands against a massive structure at the northern end and is in connection with another structure (9') oriented east to west with a possible opening or door.

Although the described shapes are well defined horizontally, their vertical definition is irregular, which could 


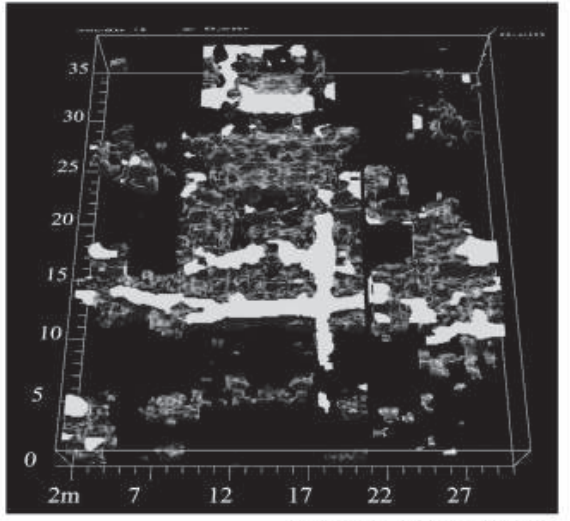

A. Central nave Isosurface $60 \%$
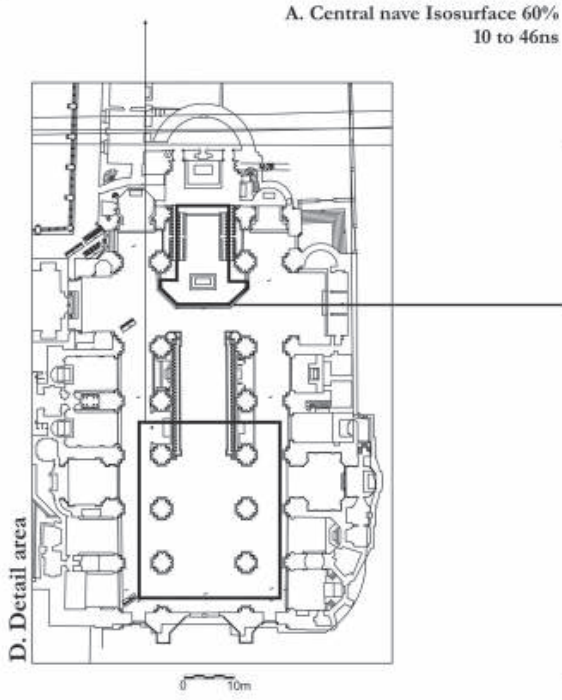

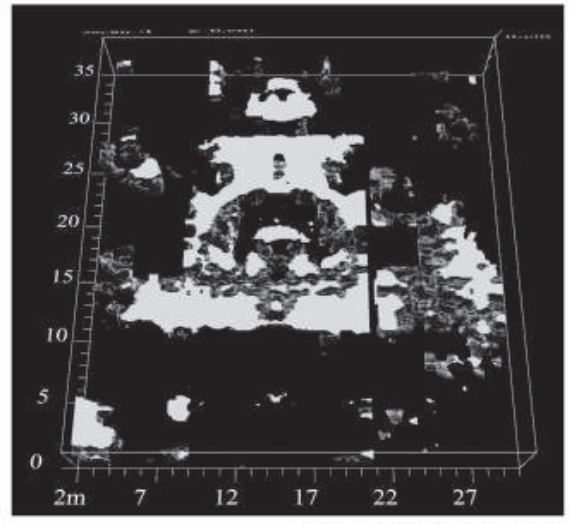

B. Central nave Isosurface $60 \%$ 22 to 46 ns

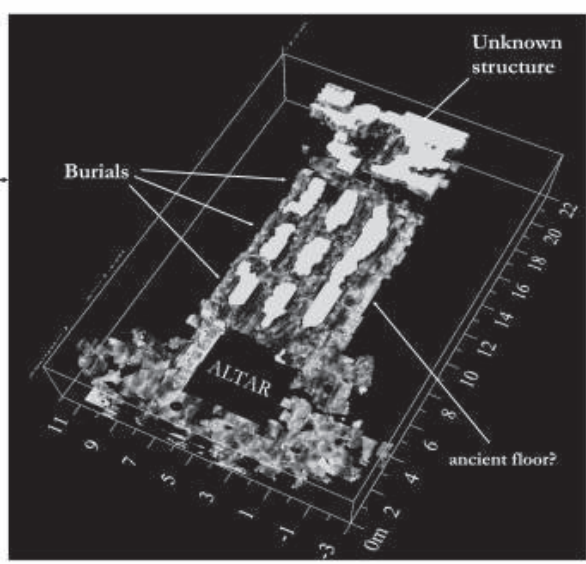

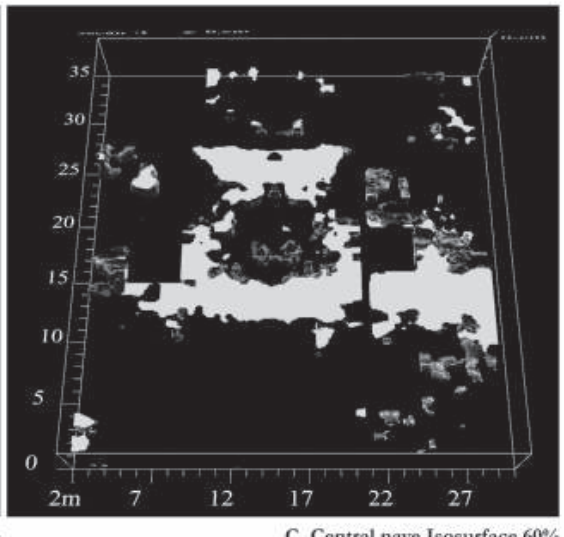

C. Central nave Isosurface $60^{\circ}$ 32 to 46 ns

Figure 2: Tarragona Cathedral survey project, GPR survey results - 3D isosurface views

Nave isosurface $60 \%-10$ to 46 ns

Nave isosurface $60 \%-22$ to $46 \mathrm{~ns}$

Nave isosurface $60 \%-32$ to $46 \mathrm{~ns}$

Detail of area

Altar isosurface $75 \%-20$ to $90 \mathrm{~ns}$

mean that the structure is not well preserved or that the superposition of various phases of construction makes the identification of each structure and of the relations between structures difficult.

In addition to the architectural analysis and interpretation, the results will have other applications. Validating this information with archaeological intervention on selected locations, the team of archaeologists will have a tool for planning future research with predefined goals.

\section{DATA FILTERING AND ANALYSIS}

For testing statistical, analytical and imaging procedures, part of a dataset collected in the nave was used, featuring $0.4 \mathrm{~m}$ spacing between transects in both $\mathrm{x}$ and $\mathrm{y}$ directions, at $40 \mathrm{scans} / \mathrm{m}(0.025 \mathrm{~m}$ per scan).

As thickness of the time window has an impact on the generated slice maps, the sensitivity to thickness had to be studied. Time-slices are usually generated computing the mean value of squared amplitude. Other statistical operators were tested in order to improve structure definition: these included standard deviation of amplitude, squared 
amplitude and magnitude, on non-interpolated data and on combined $\mathrm{X}$ and $\mathrm{Y}$ directions.

Besides the sensitivity to thickness, under the $2 \mathrm{~m}$ there is a loss of intensity and/or of signal quality. Geostatistical and statistical flowcharts were applied in order to improve data quality. They consist in generating a correction index based on the filtering of statistical 2D maps and applying this index to the $3 \mathrm{D}$ amplitude cube.

\section{References}

Macias, J. M., Menchon, J. J., Muñoz, A. and Teixell, I. 2007. Excavaciones en la Catedral de Tarragona y su entorno: avances y retrocesos en la investigación sobre el culto Imperial. Culto Imperial: política y poder, actas del Congreso Internacional (Mérida 2006), L'Erma di Bretschneider, 765-787. Roma.
Macias, J. M., Menchon, J. J., Muñoz, A. and Teixell, I., 2007. L'Arqueologia de la Catedral de Tarragona. La memòria de les pedres. In La Catedral de Tarragona. Sede, 10 anys del Pla Director de Restauració, 151-213.

CONYERs, L. B., 2004. Ground-penetrating Radar for Archaeology. AltaMira Press: Walnut, Creek, CA.

Goodman, D, Nishimura, Y and Rogers, J.D., 1995. GPR timeslice in archaeological prospection. Archaeological Prospection, 3: 85-89.

SANDJIVY, L., 1984. Analyse krigeante des données géochimiques: étude d'un cas monovariable dans le modèle stationnaire. Sciences de la terre, 18: 141-172.

Matheron, G., 1965. Les variables régionalisées et leur estimation: une application de la théorie des fonctions aléatoires aux sciences de la nature. Paris, Masson. 